\title{
Mixed-Methods and Multimethod Research
}

\author{
Felix Knappertsbusch, Bettina Langfeldt, and Udo Kelle
}

\begin{abstract}
Mixed-methods and multimethod approaches, i.e. the combination of multiple (qualitative and/or quantitative) techniques for data collection and analysis in a single research design, have developed into an established branch of empirical social research and methodology. We show that the German-speaking research landscape is no exception to this trend and provide an overview of the most widely received actors and approaches. Moreover, we argue that the German-language discourse on method integration retains a certain "qualitative" leaning, because most of its prominent authors hail from that tradition. We describe the research areas in which mixed approaches are currently most prevalent (health, education, and evaluation research), highlighting that these are mostly interdisciplinary and applied fields, while traditional core areas of sociology seem to be more reluctant to follow this trend. We conclude with a discussion of future directions for mixed and multimethod research, including its further institutionalization within professional organizations and teaching curricula, as well as building a stronger link between methodological discourse and empirical research practice.
\end{abstract}

Keywords: Mixed methods, multimethod research, triangulation, social research methodology

\section{Introduction}

A considerable number of well-known early empirical studies in the social sciences feature a combination of quantitative and qualitative methods. Popular examples include the Marienthal study (Jahoda et al., 1975) and The Authoritarian Personality (Adorno et al., 1950). Despite the success of these highly influential studies, method integration remained an uncommon practice in social research throughout most of the twentieth century. Instead, the discourse on methods was increasingly influenced by a methodological dualism that assumed that quantitative and qualitative research "paradigms" are based on incompatible epistemological premises (Guba and Lincoln, 1988). As a consequence, discussions about the 'correct' method of social research became more and more polarized during the 1960s and '70s (Teddlie and Tashakkori, 2009).

While quantitative researchers emphasize the benefits of precise measurement and quantification in order to attain generalizable, reliable, and value-free knowledge, qualitative researchers insist that the investigation of social interaction and meaning-making requires non-standardized, interpretive methods and reflexive participation of the observers. However, both types of research also have their specific weaknesses. Standardized approaches rely on extensive prior knowledge, which can 
be highly problematic when investigating the flexible and differentiated interactions and institutions of modern societies (Langfeldt and Goltz, 2017). Moreover, quantitative research tends to be quite reductionist in how it operationalizes social phenomena, thus leading to issues of construct and ecological validity (Knappertsbusch, 2017). At the same time, the reconstruction of situated meaning through qualitative methods imposes severe restrictions on the number of observed cases, which can create issues of generalizability, while both the collection and the interpretation of qualitative data strongly depend on individual researchers' perspectives, which may impede an intersubjective understanding (Kelle, 2007).

In the mid-1980s, a group of mainly Anglophone social researchers began to focus on the possibilities of applying empirical research methods beyond the established qualitative/quantitative divide. By the late 1990s, these discussions had grown into a methodological movement that advocated the systematic combination of the different approaches (Creswell and Plano-Clark, 2011). Inspired by the influential monograph Mixed Methodology (Tashakkori and Teddlie, 1998), the term "mixed methods" became a widely accepted label for the combination of qualitative and quantitative methods in a single study. ${ }^{1}$ Discussions in the developing mixed-methods community revolved around four key issues that still shape the discourse on method integration. In the earlier stages, researchers were very concerned with epistemology and philosophy of science, debating the extent to which combinations of qualitative and quantitative "paradigms" are possible at all (Caracelli and Greene, 1997). Authors then turned to questions of research design, developing several design typologies (Creswell and Plano-Clark, 2011; Teddlie and Tashakkori, 2009). Practical implications of method combination, such as sampling (Collins and Onwuegbuzie, 2007) and data-analysis techniques (Bazeley, 2018), developed as a third core area of discussion. And finally, these practical considerations became tied to the issue of quality criteria for method integration (Onwuegbuzie and Johnson, 2006).

As we will show in this chapter, mixed-methods and multimethod research (MMMR) has consolidated into an established approach in German-speaking social research communities as well. Beginning with an outline of the most influential methodological contributions to the field in section 2, we argue that despite strong influences from the Anglophone literature, the German-language discourse retains a specific 'flavor' because most of its prominent authors hail from qualitative backgrounds. Section 3 describes three interdisciplinary research areas in which method integration is most frequently applied, including educational, health, and evaluation

1 We use the term multimethod research to describe any combination of qualitative and/or quantitative methods, whereas the term mixed methods specifically refers to qualitative-quantitative combinations (Fetters and Molina-Azorin, 2017). However, acknowledging the inconsistent use of both terms, and the fuzziness of the qualitative/quantitative distinction, we also use the acronym MMMR (mixed-methods and multimethod research) to refer to the field of method integration generally (Hesse-Biber, 2015). 
research. We conclude with a discussion of current trends and future developments in the German-language mixed-methods landscape.

\section{Mapping the German-Language Methodological Discourse on MMMR}

The German-language MMMR discourse can be very roughly divided into three arenas with overlapping fields and with a variety of actors who are active in more than one arena of discourse. One centers around the notion of triangulation and highlights the far-reaching implications of a pluralistic methodology beyond the combination of qualitative and quantitative methods, with authors mostly sharing a qualitative background. A second is connected to international debates about mixed-methods designs and focuses on qualitative-quantitative combinations. It also refers to methodological, substantive theoretical, and epistemological perspectives by authors who avoid making strict commitments to a qualitative or quantitative tradition. A third focuses on multimethod approaches to the analysis of causal mechanisms via casebased or medium- $\mathrm{N}$ methods in the context of qualitative research (employing a notion of qualitative research that differs considerably from the interpretive tradition of German-language sociology). In addition to that, several more recent contributions have sought to mediate between these different discourses.

The triangulation metaphor was first applied to social-research methodology by Campbell and Fiske in the context of validation techniques for standardized methods. It gained a broader meaning in the works of Denzin in the 1970s, who described "methodological triangulation" as a strategy for combining different qualitative and/ or quantitative research approaches to increase the validity as well as the breadth and depth of findings (Flick, 2004). While the concept has since lost much of its early significance in the Anglo-American debate (Morgan, 2019), it still is very common in the German-language discourse, especially among researchers with a qualitative methodological background. Flick presents a comprehensive account of the triangulation concept in his 2004 introduction (Flick, 2004), including the integration of data sources as well as investigator perspectives, theoretical approaches, and methods. He stresses that triangulation should be distinguished from a mere accumulation of different methods in that it is characterized by the effort to construct an integrated whole from several equal status perspectives (Flick, 2004: 20ff.). Flick acknowledges mixed methods as a sub-form of triangulation but criticizes the approach for primarily focusing on methods while neglecting other important aspects of integrated research such as investigator perspectives or substantive theory. This skepticism is most apparent in his more recent work, which argues for triangulation as an alternative to mixed methods (Flick, 2017). However, this critical assessment must also be read in the context of some MMMR authors' arguments for divesting of "triangulation" as an 
unclear and outdated term for method integration (Fetters and Molina-Azorin, 2017; Morgan, 2019).

The triangulation metaphor also features prominently in Mayring's work, who is best known for his model of qualitative content analysis (Mayring, 2012; 2015). Mayring takes a more open stance towards the current MMMR discourse, describing triangulation not as an alternative to but rather as one possible mode of mixed methods that combines qualitative and quantitative methods in a concurrent design to gain a more nuanced, multifaceted picture of the research object (Mayring, 2001). A focus on content-analysis techniques can also be found in Kuckartz's work on method integration, which stems from a qualitative background. Following Max Weber's model of social-research methodology, he proposes a method for text analysis that combines hermeneutic and quantitative techniques (Kuckartz, 2012: 26ff.). In contrast to Mayring's approach, his framework for content analysis involves a rather skeptical position towards the triangulation concept (Kuckartz, 2014: 48f.), which he criticizes for not providing clear-cut guidelines for research practice. Instead, Kuckartz turns to Creswell's design-based mixed-methods approach to provide a basic framework. In his more recent work, Kuckartz has shifted his attention towards methods for integrated data analysis (Kuckartz, 2017). Building on common mixed-methods design typologies, he describes results-based, data-based, and sequence-based strategies for integrative data analysis (Kuckartz, 2017: 169ff.).

Another influential strand of MMMR discourse in Germany originated from the Special Research Area (SFB 186) "Status Passages and Risks in the Life Course." (Huinink/Hollstein, LIFE COURSE, this volume) These authors share a common interest in the methodology of qualitative research methods (Kelle, 1994; Kluge, 1999; Prein, 1996) that extends to the methodological groundwork of method integration (Erzberger and Prein, 1997; Kelle and Erzberger, 1999). They argue that prevailing debates around the concept of triangulation do not sufficiently take research practice into account and that the whole concept is too ambiguous to serve as a methodological basis for method integration. Instead of referring to abstract epistemological concepts and metaphors like triangulation, they maintain that researchers should be intensively relating methodological considerations to social theory. A central building block of this perspective is the "duality of structure" as described by Giddens (1984), which assumes a reciprocal relation between social structures and individual agency. If empirical research does not take this reciprocity into account systematically, researchers' interpretations of structural phenomena run the risk of misrepresenting their situated, practical meaning, while intensive analyses of localized practice are in danger of overgeneralizing their findings (Erzberger and Kelle, 2003: 473). Considering the complementary strengths and weaknesses of qualitative and quantitative methods, these authors view a combination of both approaches to be a promising prospect for developing and testing "middle range theories" and sociological macro-micro explanations (Kelle, 2007: 271ff.). (Schützeichel, MICROSOCIOLOGY, this volume)

The research network "Mixed Methods and Multimethod Social Research," initiated by a group of German-speaking MMMR scholars in 2018, has adopted a mediating 
position between the opposing perspectives of triangulation and mixed-methods research. ${ }^{2}$ It works to improve the quality and prevalence of MMMR, promotes interdisciplinary and international dialogue between researchers, and aims to increase the visibility and intensity of the MMMR debate. Burzan, as one of several associated members of this network, has proposed a framework for "methodologically pluralist research" (Burzan, 2016). While she criticizes mixed-methods researchers' tendency to neglect theoretical and epistemological considerations, she also points to triangulation's somewhat vague stance between validation and perspectivism. However, Burzan's approach retains a close affinity to qualitative research traditions. This is apparent in her highlighting of the distinction between qualitative versus interpretive methods, the latter of which involves the reconstruction of highly case-specific meaning-making by applying hermeneutical methods (Burzan, 2016: 18). Two additional authors have taken a mediating position: Baur, whose work has mainly been on methods of social-process analysis (Baur and Ernst, 2011) and market sociology (Baur, 2011), has recently co-edited a special issue of the Kölner Zeitschrift für Soziologie und Sozialpsychologie (Baur et al., 2017) that offers a broad, inclusive overview of current German-language and Anglophone mixed-methods research. Hollstein, predominantly working in life-course research, has compiled a broad array of approaches in her co-edited volume Mixed Methods Social Network Research (Domínguez and Hollstein, 2014), with methods ranging from narrative document analysis, through surveys and ethnographies to computer simulations.

Somewhat detached from the mixed-methods discourse presented above, settheoretic and case-study methods have developed into another important strand of multimethod research (Goertz, 2017). Originating mainly from the area of comparative political science, these approaches are increasingly applied in sociological research as well (Buche and Siewert, 2015). They mostly center around Ragin's method of qualitative comparative analysis (QCA), which is often described as a "mixed method in itself" because it integrates a highly formalized method of comparison with detailed case-specific knowledge (Hollstein and Wagemann, 2014: 247ff.). Moreover, QCA can also be combined with other methods of causal analysis, such as case-based "processtracing” (Schneider and Rohlfing, 2013), whereas some multimethod designs do not use QCA at all and employ combinations of case studies and statistical analysis or experiments instead (Goertz, 2017).

2 The network is currently funded by the German Research Foundation (project no. 374277577). For more information, please visit https://www.hsu-hh.de/methoden/en/mixed-methods-network 


\section{Major Areas of MMMR Application in Social Research}

The application of MMMR designs today is a widespread practice throughout various social-research disciplines (Truscott et al., 2010; Alise and Teddlie, 2010). However, not all of these applications also refer to the discourse of what Maxwell (2018) calls the "self-identified" mixed-methods community. MMMR concepts and terminology are currently most prominent in the fields of education, health and nursing, and evaluation research, which were also the main fields from which the mixed-methods movement originated in the 1980s and '90s (Creswell and Plano-Clark, 2011: 20). We propose that the German-language MMMR landscape largely mirrors this pattern. This is not to say that MMMR does not play any significant role in more traditional areas of sociology. However, an overview of current German-language MMMR cannot ignore the fact that method integration is still mostly taking place in interdisciplinary and applied fields while sociological core areas remain strongly shaped by the qualitative/ quantitative divide.

In health research, method integration is mainly motivated by the need to provide more detailed investigations of public-health phenomena as well as more valid assessments for evidence-based medicine (Kelle and Krones, 2010). The interest in mixed methods, however, often remains somewhat limited to the ostensibly 'softer' areas of nursing, counseling, and psychotherapy, which traditionally are closer to social-science methodology than life-science-oriented sub-fields. Overall, the MMMR discourse in health research seems to be strongly influenced by a quantitative perspective. This is evident in the dominance of quantitative core-components in the applied designs (quasi-experiments or randomized controlled trials), whereas studies with equally weighted qualitative and quantitative strands are often met with skepticism. This seems somewhat unfortunate, considering that health research involves a close integration of subject-oriented micro perspectives and the meso and macro levels of institutional settings and economic or political structures (Niederberger, 2018: 86). Hesitant adoption of MMMR approaches may also be due to the strictly formalized quality criteria in evidence-based health research, which do not accommodate method integration in their current form (Niederberger and Peter, 2018: 10). Hence, the further development of MMMR health research depends on the advancement of sophisticated and applicable quality criteria for method integration (Mayring, 2017).

Owing to its epistemological traditions ranging from philosophical pragmatism to early behavioral psychology (Schwippert, 2012:101ff.), educational research has a long history of methodological pluralism. Systematic reviews estimate the prevalence of MMMR to be anywhere from 13\% (Truscott et al., 2010) to 24\% (Alise and Teddlie, 2010). German-language educational research is no exception to this trend, as can be seen from the high number of MMMR-related field-specific anthologies (GläserZikuda et al., 2012; Hofmann et al., 2008; Ecarius and Miethe, 2011). This integrative methodological orientation is also a result of the discipline's humanist traditions 
being confronted by a growing demand for large-scale quantitative evaluations. Moreover, the objects of educational research often involve complex multilevel phenomena, which suggest the combination of different methods. Additionally, doing research with youth and children involves specific challenges for data collection, leading to an increased importance of observational and visual methods, which results in a growing demand for method integration (Seidel and Thiel, 2017). Despite ongoing quarrels between interpretivist and standardized approaches, this has led some researchers to claim that method integration constitutes the current "state of the art" in educational research (Schwippert, 2012: 110). However, this effect seems especially pronounced in areas with a strong focus on applied research, such as didactics (Kelle et al., 2019), whereas areas dedicated more to basic research tend to remain divided along the lines of the qualitative/quantitative distinction. (Grundmann, EDUCATION AND SOCIALIZATION, this volume)

Evaluation research, which is part of several fields of sociology, often involves a dual focus on assessing the impact of a given intervention as well as understanding the causal mechanisms behind it, which makes it a prime example of the productivity of method integration (Kelle, 2018). Whereas standardized and statistical approaches are particularly well suited for observing the regularity and strength of expected causal effects, qualitative methods are an indispensable tool for discovering unanticipated side effects and confounding factors. This potential of MMMR designs is acknowledged by the German Evaluation Society (Deutsche Gesellschaft für Evaluationsforschung; DeGEval), and method integration is a regular topic in the Association's own journal, Zeitschrift für Evaluation (Mayring et al., 2016). Also, the DeGEval methods working group has been discussing applications of MMMR regularly since its founding in 2010 (Caspari and Polak, 2017). One of the growing research areas in which MMMR designs are used for evaluation purposes is international development assistance (Mayring et al., 2016: 17). Several good examples of a productive use of MMMR in this area can be found in the work of the German Institute for Development Evaluation (Deutsches Evaluierungsinstitut der Entwicklungszusammenarbeit; DEval). Research conducted by this government-funded organization regularly employs complex multiphase designs (Polak et al., 2017) while also highlighting the importance of an elaborate conceptual foundation. Despite their clear focus on evidencebased policy decisions, DEval researchers often devise a sophisticated "theory of change" as the groundwork for their empirical observation (Leppert et al., 2018: 21).

\section{Conclusion}

The MMMR movement has grown into an established branch of German-language social research. A slight departure from the Anglophone discourse is evident in the relatively strong influence of qualitative research perspectives, which is associated with a continuing significance of the triangulation concept. However, despite its qualitative leanings, MMMR is sometimes met with skepticism by qualitative re- 
searchers who question its compatibility with interpretive methods 'proper.' At the same time, quantitative researchers tend to accept the idea of method integration more readily but often assume that it is something they have been doing anyway (e.g., in cognitive pretest interviews), which also amounts to an incomplete recognition of the ramifications of MMMR.

The overall trend of a growing MMMR discourse is reflected in the increasing number of German-language methods textbooks featuring qualitative, quantitative, and mixed approaches from a pluralistic perspective (Baur and Blasius, 2014; Flick, 2016). Even some standard textbooks with a traditionally quantitative orientation are now starting to systematically incorporate method integration (Döring and Bortz, 2016.). This development can be considered a small but important step towards more inclusive methods curricula in social-science study programs.

Even though MMMR has gained a more stable footing, however, the overall academic landscape is still shaped by qualitative and quantitative research traditions. MMMR methodologists and researchers remain a somewhat alien minority in many institutional environments, whereas qualitative and quantitative traditions largely carry on with their established routines. Hence, a stronger institutionalization of MMMR perspectives remains a central objective for future development, including better representation in professional organizations, on editorial boards, and on review committees.

MMMR is already a diverse and multidisciplinary research landscape and will likely branch out even further. There is nevertheless a substantial lack of systematic reviews that assess the prevalence and quality of MMMR today. An important aspect of future research will therefore be to increase the scope of a systematic, comparative “prevalence rates literature" (Alise and Teddlie, 2010). This also involves a fuller recognition of the limited reach of the current methodological MMMR discourse. Reviews show that a large proportion of studies using method integration do not label their work as MMMR at all, which suggests that considerable mutual learning opportunities still exist.

\section{References}

Adorno, T. W.; Frenkel-Brunswik, E.; Levinson, D. J.; Sanford, R. N. The Authoritarian Personality; Harper \& Brothers: New York, 1950.

Alise, M. A.; Teddlie, C. A Continuation of the Paradigm Wars? Prevalence Rates of Methodological Approaches across the Social/Behavioral Sciences. Journal of Mixed Methods Research 2010, 2, 103-126.

Baur, N. Mixing Process-Generated Data in Market Sociology. Quality \& Quantity 2011, 6, 1233-1251.

Baur, N.; Blasius, J., Eds. Handbuch Methoden der empirischen Sozialforschung; Springer VS: Wiesbaden, 2014.

Baur, N.; Ernst, S. Towards a Process-Oriented Methodology: Modern Social Science Research Methods and Norbert Elias's Figurational Sociology. The Sociological Review 2011, 59, 117-139. 
Baur, N.; Kelle, U.; Kuckartz, U. Mixed Methods - Stand der Debatte und aktuelle Problemlagen. Kölner Zeitschrift für Soziologie und Sozialpsychologie 2017, 69, 1-37.

Bazeley, P. Integrating Analyses in Mixed Methods Research; SAGE: Los Angeles/London/New Delhi, 2018.

Buche, J.; Siewert, M. Qualitative Comparative Analysis (QCA) in der Soziologie - Perspektiven, Potentiale und Anwendungsbereiche. Zeitschrift für Soziologie 2015, 6, 386-406.

Burzan, N. Methodenplurale Forschung. Chancen und Probleme von Mixed Methods; Beltz Juventa: Weinheim/Basel, 2016.

Caracelli, V. J.; Greene, J. C. Defining and Describing the Paradigm Issue in Mixed-Method Evaluation. In Advances in Mixed Method Evaluation. The Challenges and Benefits of Integrating Diverse Paradigms; Greene, J. C.; Caracelli, V. J., Eds.; Jossey-Bass: San Francisco, 1997; pp 5-17.

Caspari, A.; Polak, J. T. Der Arbeitskreis "Methoden in der Evaluation". Zeitschrift für Evaluation 2017, 2, 280-283.

Collins, K. M. T.; Onwuegbuzie, A. J. A Typology of Mixed Methods Sampling Designs in Social Science Research. The Qualitative Report 2007, 2, 281-316.

Creswell, J. W.; Plano-Clark, V. L. Designing and Conducting Mixed Methods Research; SAGE: Los Angeles, 2011.

Döring, N.; Bortz, J. Forschungsmethoden und Evaluation in den Sozial- und Humanwissenschaften; Springer: Berlin/Heidelberg, 2016.

Domínguez, S.; Hollstein, B., Eds. Mixed Methods Social Networks Research. Design and Applications; Cambridge University Press: New York, 2014.

Ecarius, J.; Miethe, I., Eds. Methodentriangulation in der qualitativen Bildungsforschung; Budrich: Opladen, 2011.

Erzberger, C.; Kelle, U. Making Inferences in Mixed Methods: The Rules of Integration. In Handbook of Mixed Methods in Social \& Behavioral Research; Tashakkori, A.; Teddlie, C., Eds.; SAGE: Thousand Oaks, 2003; pp 457-489.

Erzberger, C.; Prein, G. Triangulation: Validity and Empirically-Based Hypothesis Construction. Quality and Quantity 1997, 2, 141-154.

Fetters, M. d.; Molina-Azorin, J. F. The Journal of Mixed Methods Research Starts a New Decade: Principles for Bringing in the New and Divesting of the Old Language of the Field. Journal of Mixed Methods Research 2017, 1, 3-10.

Flick, U. Triangulation. Eine Einführung; VS: Wiesbaden, 2004.

Flick, U. Sozialforschung. Methoden und Anwendungen: ein Überblick für die BA-Studiengänge; Rowohlt: Reinbek near Hamburg, 2016.

Flick, U. Mantras and Myths: The Disenchantment of Mixed-Methods Research and Revisiting Triangulation as a Perspective. Qualitative Inquiry 2017, 1, 46-57.

Giddens, A. The Constitution of Society. Outline of the Theory of Structuration; University of California Press: Berkeley, 1984.

Gläser-Zikuda, M.; Seidel, T.; Rohlfs, C.; Gröschner, A., Eds. Mixed methods in der empirischen Bildungsforschung; Waxmann: Münster/New York/Munich/Berlin, 2012.

Goertz, G. Multimethod research, Causal Mechanisms, and Case Studies. An Integrated Approach; Princeton University Press: Princeton/Oxford, 2017.

Greene, J. C. With a Splash of Soda, Please: Towards Active Engagement with Difference. Evaluation 2002, 2, 259-266.

Guba, E. G.; Lincoln, Y. S. Do Inquiry Paradigms Imply Inquiry Methodologies? In Qualitative Approaches to Evaluation in Education. The Silent Scientific Revolution; Fetterman, D. M., Eds.; Praeger: New York, 1988; pp 88-115.

Hesse-Biber, S. Introduction: Navigating a Turbulent Research Landscape: Working the Boundaries, Tensions, Diversity, and Contradictions of Multimethod and Mixed Methods Inquiry. In The 
Oxford Handbook of Multimethod and Mixed Methods Research Inquiry; Hesse-Biber, S.; Johnson, R. B., Eds.; Oxford University Press: New York, 2015; pp xxxiii-liii.

Hofmann, F.; Schreiner, C.; Thonhauser, J., Eds. Qualitative und quantitative Aspekte. Zu ihrer Komplementarität in der erziehungswissenschaftlichen Forschung; Waxmann: Münster, 2008.

Hollstein, B.; Wagemann, C. Fuzzy-Set Analysis of Network Data as Mixed Method: Personal Networks and the Transition from School to Work. In Mixed Methods Social Networks Research. Design and Applications; Domínguez, S.; Hollstein, B., Eds.; Cambridge University Press: New York, 2014; 237-268.

Jahoda, M.; Lazarsfeld, P. F.; Zeisel, H. Die Arbeitslosen von Marienthal. Ein soziographischer Versuch; Suhrkamp: Frankfurt a.M., 1975.

Johnson, R. B. Dialectical Pluralism: A Metaparadigm Whose Time Has Come. Journal of Mixed Methods Research 2017, 11, 156-173.

Kelle, U. Empirisch begründete Theoriebildung. Zur Logik und Methodologie interpretativer Sozialforschung; Deutscher Studien-Verlag: Weinheim, 1994.

Kelle, U. Die Integration qualitativer und quantitativer Methoden in der empirischen Sozialforschung. Theoretische Grundlagen und methodologische Konzepte; VS: Wiesbaden, 2007.

Kelle, U. "Mixed Methods" in der Evaluationsforschung - mit den Möglichkeiten und Beschränkungen quantitativer und qualitativer Methoden arbeiten. Zeitschrift für Evaluation 2018, 1, 25-52.

Kelle, U.; Erzberger, C. Integration qualitativer und quantitativer Methoden. Methodologische Modelle und ihre Bedeutung für die Forschungspraxis. Kölner Zeitschrift für Soziologie und Sozialpsychologie 1999, 3, 509-531.

Kelle, U.; Krones, T. "Evidence based Medicine" und "Mixed Methods" - wie methodologische Diskussionen in der Medizin und den Sozialwissenschaften voneinander profitieren könnten. Zeitschrift für Evidenz, Fortbildung und Qualität im Gesundheitswesen 2010, 8-9, 630-635.

Kelle, U.; Kühberger, C.; Bernhard, R. How to Use Mixed-Methods and Triangulation Designs: an Introduction to History Education Research. History Education Research Journal 2019, 1, 5-23.

Kluge, S. Empirisch begründete Typenbildung. Zur Konstruktion von Typen und Typologien in der qualitativen Sozialforschung; Leske + Budrich: Opladen, 1999.

Knappertsbusch, F. Ökologische Validität durch Mixed-Methods-Designs. Die Nutzung qualitativer Interviews zur komplementären Ergänzung standardisierter Vorurteilsmessung. Kölner Zeitschrift für Soziologie und Sozialpsychologie 2017, 69, 337-360.

Kuckartz, U. Qualitative Inhaltsanalyse. Methoden, Praxis, Computerunterstützung; Beltz-Juventa: Weinheim, 2012.

Kuckartz, U. Mixed Methods. Methodologie, Forschungsdesigns und Analyseverfahren; Springer VS: Wiesbaden, 2014.

Kuckartz, U. Datenanalyse in der Mixed-Methods-Forschung. Kölner Zeitschrift für Soziologie und Sozialpsychologie 2017, 69, 157-183.

Langfeldt, B.; Goltz, E. Die Funktion qualitativer Vorstudien bei der Entwicklung standardisierter Erhebungsinstrumente. Ein Beispiel aus der Evaluationsforschung im militärischen Kontext. Kölner Zeitschrift für Soziologie und Sozialpsychologie 2017, 69, 313-335.

Leppert, G.; Hohfeld, L.; Lech, M.; Wencker, T. Impact, Diffusion and Scaling-Up of a Comprehensive Land-Use Planning Approach in the Philippines. From Development Cooperation to National Policies; German Institute for Development Evaluation: Bonn, 2018.

Maxwell, J. A. The "Silo Problem" in Mixed Methods Research. International Journal of Multiple Research Approaches 2018, 1, 317-327.

Mayring, P. Kombination und Integration qualitativer und quantitativer Analyse. Forum: Qualitative Sozialforschung 2001, 1, Article 6. 
Mayring, P. Qualitative Inhaltsanalyse - ein Beispiel für Mixed Methods. In Mixed Methods in der empirischen Bildungsforschung; Gläser-Zikuda, M.; Seidel, T.; Rohlfs, C.; Gröschner, A., Eds.; Waxmann: Münster/New York/Munich/Berlin, 2012; pp 27-36.

Mayring, P. Qualitative Inhaltsanalyse. Grundlagen und Techniken; Beltz: Weinheim/Basel 2015.

Mayring, P. Evidenztriangulation in der Gesundheitsforschung. Kölner Zeitschrift für Soziologie und Sozialpsychologie 2017, 69, 415-434.

Mayring, P.; Kerlen, C.; Sheikh, S.; Hense, J.; Schwab, O. Zwanzig Jahre DeGEval - Historie, Entwicklungen, Herausforderungen. Zeitschrift für Evaluation 2016, 2, 13-31.

Morgan, D. L. Commentary-After Triangulation, What Next? Journal of Mixed Methods Research 2019, 1, 6-11.

Niederberger, M. Mixed-Methods-Studien in der Gesundheitsförderung. Prävention und Gesundheitsförderung 2018, 1, 85-90.

Niederberger, M.; Peter, L. Mixed-Methods-Studien in den Gesundheitswissenschaften. Ein kritischer Überblick. Zeitschrift für Evidenz, Fortbildung und Qualität im Gesundheitswesen 2018, 9-23.

Onwuegbuzie, A. J.; Johnson, R. B. The Validity Issue in Mixed Methods. Research in the Schools 2006, 1, 48-63.

Polak, J. T.; Guffler, K.; Scheinert, L. Weltwärts-Freiwillige und ihr Engagement in Deutschland; Deutsches Evaluierungsinstitut der Entwicklungszusammenarbeit: Bonn, 2017.

Prein, G. Interpretative Methodologie und Computer. Kann EDV-gestützte Datenverwaltung Validitätsprobleme qualitativer Forschung lösen? In Wahre Geschichten? Zu Theorie und Praxis qualitativer Interviews; Böttger, A.; Strobl, R., Eds.; Nomos: Baden-Baden, 1996; pp 93-110.

Schneider, C. Q.; Rohlfing, I. Combining QCA and Process Tracing in Set-Theoretic Multi-Method Research. Sociological Methods \& Research 2013, 4, 559-597.

Schwippert, K. Empirische Bildungsforschung: Perspektiven der Erziehungswissenschaft. DDS - Die Deutsche Schule 2012, 1, 100-112.

Seidel, T.; Thiel, F. Standards und Trends der videobasierten Lehr-Lernforschung. Zeitschrift für Erziehungswissenschaft 2017, 20, 1-21.

Tashakkori, A.; Teddlie, C. Mixed Methodology. Combining Qualitative and Quantitative Approaches; SAGE: Thousand Oaks, 1998.

Teddlie, C.; Tashakkori, A. Foundations of Mixed Methods Research. Integrating Quantitative and Qualitative Approaches in the Social and Behavioral Sciences; SAGE: Los Angeles, 2009.

Truscott, D. M.; Swars, S.; Smith, S.; Thornton-Reid, F.; Zhao, Y.; Dooley, C.; Williams, B.; Hart, L.; Matthews, M. A Cross-Disciplinary Examination of the Prevalence of Mixed Methods in Educational Research 1995-2005. International Journal of Social Research Methodology 2010, 4, 317-328. 
